\title{
Dekriminalisasi Eutanasia pada Praktik Medis dalam Sistem Hukum Pidana di Indonesia
}

\author{
Decriminalization of Euthanasia in Medical Practice in the Indonesia \\ Criminal Law System
}

\author{
Yudi Susanto Wijaya \\ Kantor Wilayah Kementerian Hukum dan Hak Asasi Manusia Sulawesi Tenggara \\ E-mail: yudirutan2009@gmail.com \\ Sabrina Hidayat \\ Pascasarjana Universitas Halu Oleo \\ E-mail: sabrina.hidayat54@yahoo.com \\ Handrawan \\ Pascasarjana Universitas Halu Oleo \\ E-mail: handrawansaranani84@gmail.com
}

\begin{abstract}
The aim of this research is to analyze euthanasia on de-criminalization perspective as well as to study criminal policy the euthanasia de-criminalization. This legal research applied statute, concepts, and comparative approach including primer and secondary analysis technically. To sump with result is that euthanasia in Indonesia is can be considered as decriminalization. Notwithstanding euthanasia nowadays is a crime offence that must be punished. Nevertheless, euthanasia decriminalization in Indonesia should be measured as practiced as several states such as Netherlands, Belgium even in Anglo Saxon system such as United State of America and Australia. In consequence, euthanasia decriminalization is able to apply by means of comparative approach. Euthanasia decriminalization is able committed to crime that is approved by a doctor. Subsequently, the criminal policy of euthanasia decriminalization is able committed to crime for suffered patient for long time. In addition, euthanasia decriminalization must be approved by Indonesia Supreme Court. Lastly, euthanasia decriminalization is able committed to crime with health reason, not by ages, families, and psychology reasons.
\end{abstract}

Keyword: Decriminalization; Euthanasia; Medical Practice

Abstrak: Tujuan penelitian ini adalah untuk menganalisis eutanasia dapat dekriminalisasi dan untuk menganalisis mengkaji kebijakan hukum pidana tentang dekriminalisasi eutanasia. Penelitian hukum ini menggunakan pendekatan perundang-undangan (statute approach), Pendekatan konseptual (conseptual approach) dan Pendekatan komparatif (comparative approach) dengan bahan hukum primer dan sekunder dengan teknis analisis preskriptif. Berdasarkan hasil penelitian bahwa eutanasia dapat dekriminalisasi di Indonesia. Meskipun saat ini eutanasia merupakan tindak pidana yang dapat dimintakan 
pertanggungjawaban pidana. Namun demikian, ruang hukum dekriminalisasi eutanasia perlu diatur, sebagaimana yang telah dipraktikkan di negara-negara yang menganut sistem hukum yang sama dengan Indonesia seperti Belanda dan Belgia dan bahkan di negara Anglo Saxon seperti Amerika dan Australia telah memberikan ruang hukum dekriminalisasi eutanasia. Oleh sebab itu konsep dekriminalisasi eutanasia dapat saja diwujudkan melalui pendekatan perbandingan hukum. Dekriminalisasi eutanasia hanya dapat diwujudkan apabila ada permohonan sungguh-sungguh dan terus menerus dari pasien dan secara medis tidak dapat disembuhkan berdasarkan kesimpulan dokter. Kebijakan hukum pidana tentang dekriminalisasi eutanasia yaitu Dekriminalisasi eutanasia hanya dapat dilakukan terhadap pasien yang dalam keadaan menderita terus menerus, tak tertahankan dan tidak dapat disembuhkan, Dekriminalisasi eutanasia dapat dilakukan berdasarkan hasil penelitian medis terpadu. Eutanasia dapat dilakukan apabila permintaan untuk mati harus dilakukan secara sukarela, independen dan terus menerus dan hanya dapat diterapkan berdasarkan penetapan Mahkamah Agung. Pada akhirnya, dekriminalisasi eutanasia hanya dapat diterapkan dengan alasan kesehatan bukan alasan usia, alasan keluarga dan alasan psikis.

Kata kunci: Dekriminalisasi; Eutanasia; Praktik Medis

\section{PENDAHULUAN}

Setiap manusia berhak mendapatkan perawatan medis untuk dapat pulih dari penyakit karena hal tersebut adalah kebutuhan dasar manusia (The needed of medical treatment in order to recover from the disease, it is part of the basic need as human being) ${ }^{1}$. Pernyataan di atas merupakan prinsip dasar hak asasi manusia di bidang kesehatan yang tidak dapat dibatasi dan atau dikurangi dalam keadaan apa pun (derogable right) ${ }^{2}$. Di Indonesia Sampai saat ini, eutanasia masih menimbulkan pro dan kontra di masyarakat ${ }^{3}$. Kitab Undang-Undang Hukum Pidana (Selanjutnya Disebut KUHP) hanya melihat dari sisi dokter sebagai pelaku utama eutanasia, khususnya eutanasia aktif yang dianggap sebagai pembunuhan berencana, atau dengan sengaja menghilangkan nyawa seseorang. Sehingga dalam aspek hukum, dokter selalu pada pihak yang dipersalahkan dalam tindakan eutanasia, tanpa melihat latar belakang

1 Sabrina Hidayat, "Evidence Doctor Error in Alleged of Criminal Act on Medical Malpractice”, International Journal of Scientific \& Technology Research Volume 4, Issue 02, February 2015, hlm. 1.

2 Handrawan, "Pemulihan Hak Politik Melalui Mekanisme Konstitusional”, Halu Oleo Law Review, Volume 2 Issue 1, March 2018, hlm. 404.

3 Mereka yang menyetujui tindakan eutanasia berpendapat bahwa eutanasia adalah suatu tindakan yang dilakukan dengan persetujuan serta dilakukan dengan tujuan utama menghentikan penderitaan pasien. Prinsip kelompok ini adalah manusia tidak boleh dipaksa untuk menderita. Dengan demikian, tujuan utama kelompok ini yaitu meringankan penderitaan pasien dengan memperbaiki risiko hidupnya. Kelompok yang kontra terhadap eutanasia berpendapat bahwa eutanasia merupakan tindakan pembunuhan terselubung, karenanya bertentangan dengan kehendak Tuhan. Kematian adalah sematamata adalah hak dari Tuhan, sehingga manusia sebagai makhluk ciptaan Tuhan tidak mempunyai hak untuk menentukan kematiannya. Endang Kusumah Astuti, Hubungan Hukum Antara Dokter dan Pasien Dalam Upaya Pelayanan Medis, Bandung: Citra Aditya Bakti, 2003, hlm. 64. 
dilakukannya eutanasia tersebut, tidak peduli apakah tindakan tersebut atas permintaan pasien itu sendiri atau keluarganya, untuk mengurangi penderitaan pasien dalam keadaan sekarat atau rasa sakit yang sangat hebat yang belum diketahui pengobatannya. Di lain pihak, hakim dapat menjatuhkan pidana mati bagi seseorang yang masih segar bugar yang tentunya masih ingin hidup, tidak menghendaki kematiannya seperti pasien yang sangat menderita tersebut, tanpa dijerat pasal-pasal dalam KUHP4.

Penerapan eutanasia di Indonesia masih menjadi pro dan kontra dalam dunia kesehatan. Indonesia sampai sekarang eutanasia merupakan perbuatan tindak pidana sebagaimana yang telah diatur di dalam KUHP dengan alasan apa pun. Hal ini justru menjadi problematik dalam dunia medis dimana penerapan eutanasia di Indonesia masih belum ada regulasi yang mengatur mengenai penerapannya di Indonesia baik dalam Undang-Undang 36 Tahun 2009 tentang kesehatan, Peraturan Menteri maupun dalam Kitab Undang-Undang Hukum Pidana yang secara eksplisit tidak menjelaskan tentang kebolehan penerapan eutanasia di Indonesia sehingga hal ini menjadi masalah yang kerap kali muncul dalam dunia kesehatan, berbeda halnya dengan penerapan eutanasia di Belanda yang melegalkan eutanasia dengan berbagai pertimbangan dan memberikan manfaat yang baik bagi masyarakat.

Di Indonesia, praktik upaya eutanasia pasif pernah terjadi dalam kasus Agian yang karena lama tidak sadarkan diri dari sakitnya membuat sang suami minta agar RS menyuntik mati saja (eutanasia), tapi ditolak. Menurut dr. Marius Widjajarta, apa yang dilakukan RS terhadap Agian sudah masuk kategori eutanasia pasif. "Sebenarnya pihak RS sudah melaksanakan eutanasia pasif. Kalau orang yang tidak punya uang dan membuat suatu pernyataan tidak mau dirawat, itu sudah merupakan eutanasia pasif meskipun eutanasia dapat diancam hingga 12 tahun penjara," kata Marius dari Yayasan Konsumen Kesehatan Indonesia menjawab pertanyaan wartawan.

Seperti diketahui, Agian Isna Nauli (33) hingga kini dirawat di bagian stroke RSCM, Jakarta, setelah berbulan-bulan tidak sadarkan diri pasca melahirkan. Karena ketiadaan biaya, suaminya (Hassan Kusuma) meminta RSCM menyuntik mati istrinya karena dirasa tidak ada harapan hidup normal kembali. Tapi RSCM menolak menyuntik mati Agian karena secara kedokteran tidak bisa dikatakan koma meskipun dia tidak bisa melakukan kontak.

4 Bridge D. Onwuteaka-Philipsen, "Euthanasia and other end-of-life decisions in the Netheroands in 1990, 1995 and 2001", The Lancet, Juni 2003, http://image.thelancet.com/extras/03art3297web.pdf, diakses pada tanggal 17 April 2021. 
Dalam istilah kedokteran, pasien mengalami gangguan komplikasi, digolongkan sebagai stroke, sehingga tidak ada alasan untuk eutanasia. Selain itu, di Indonesia, eutanasia tidak dibenarkan dalam etika dokter juga dalam hukum "Jadi saya rasa, kalau pembiayaan kesehatan sudah ditanggung negara dengan disahkannya Undang-Undang Sistem Jaminan Sosial, maka saya rasa kasus-kasus eutanasia tidak terulang lagi," sambung dr. Marius. Bagaimana dengan permintaan eutanasia bukan alasan biaya, tapi karena tidak punya harapan hidup "Karena itulah sudah dianjurkan pada pemerintah, profesi, ahli hukum, dan agama, kalau eutanasia diatur lagi sesuai peraturan. Jangan seperti sekarang, boleh atau tidak boleh. Tetapi, harus ada jalan keluarnya bahwa pasien mempunyai hak untuk memilih 5 .

Pelegalan eutanasia dimungkinkan terjadi dengan syarat-syarat tertentu dalam sistem hukum pidana di Indonesia demi memberikan manfaat kepada pasien dan keluarganya serta melindungi dokter dari ancaman hukuman pidana di Indonesia. Seorang pasien yang telah ditetapkan mengalami kematian batang otak berarti secara klinis dan legalformal telah meninggal dunia. Hal ini seperti dituangkan dalam pernyataan IDI tentang mati, yaitu dalam Surat Keputusan PB IDI Nomor.336/PB IDI/a.4 tertanggal 15 Maret 1988 yang disusulkan dengan Surat Keputusan PB IDI Nomor.231/PB.A.4/07/90. Dalam fatwa tersebut dinyatakan bahwa seorang dikatakan mati, bila fungsi pernafasan dan jantung telah berhenti secara pasti atau irreversible, atau terbukti telah terjadi kematian batang otak.

Dengan demikian seseorang yang telah didiagnosis secara klinis oleh pihak medis mengalami kematian batang otak maka tidak ada kemungkinan seseorang tersebut dapat hidup kembali dengan artian akan mengalami kematian. Keadaan seperti ini tidak memungkinkan seseorang dapat bertahan hidup dengan waktu yang lama. Hal inilah yang menjadi tolak ukur pelaksanaan eutanasia di Indonesia, akan tetapi masih banyak pihak medis yang belum berani mengambil tindakan terkait hal ini padahal telah diketahui secara klinis seseorang yang telah mengalami kematian batang otak tidak memungkinkan untuk bertahan hidup. Implementasi SK PB IDI tersebut belum berlaku secara utuh sehingga penerapan eutanasia di Indonesia tidak dilegalkan ${ }^{6}$.

5 "Kasus Ny Agian, RS Telah Lakukan Euthanasia Pasif", Detikcom, 16 Oktober 2004, https://news.detik.com/berita/d-225608/kasus-ny-agian-rs-telah-lakukan-euthanasia-pasif, diakses pada tanggal 17 April 2021.

6 Irna Tilamuhu, "Euthanasia Ditinjau Dari Aspek Hukum dan KUHP Indonesia", http://irnatilamuhu.blogspot.com/2012/03/euthanasia-ditinjau-dari-aspek-hukum.html. diakses pada tanggal 3 Februari 2019. 
Problem mendasar dari permasalahan tersebut adalah tidak adanya ruang di dalam hukum Pidana yang memberikan kebolehan untuk melakukan eutanasia sehingga apabila dokter melakukan tindakan tersebut maka perbuatannya dapat dikualifikasikan sebagai suatu kejahatan yang dapat dimintakan pertanggungjawaban pidana yang dapat berakibat pada pemidanaan tetapi di sisi lain SK PB IDI memberikan ruang kebolehan untuk melakukan eutanasia dengan syarat tertentu.

\section{METODE PENELITIAN}

Tipe penelitian ini menggunakan tipe penelitian hukum. Metode pendekatan yang digunakan dalam penelitian ini adalah Pendekatan perundang-undangan (statute approach), Pendekatan konseptual (conseptual approach) dan Pendekatan komparatif (comparaitve approach) dengan bahan hukum primer dan sekunder dengan teknis analisis preskriptif.

\section{ANALISIS DAN PEMBAHASAN}

\section{Eutanasia dapat Didekriminalisasi}

Konstruksi yuridis eutanasia munculnya pro dan kontra seputar persoalan eutanasia menjadi beban tersendiri bagi komunitas hukum. Sebab, pada persoalan "legalitas" inilah persoalan eutanasia akan bermuara. Kejelasan tentang sejauh mana hukum (pidana) positif memberikan regulasi/pengaturan terhadap persoalan eutanasia akan sangat membantu masyarakat di dalam menyikapi persoalan tersebut. Lebih-lebih di tengah kebingungan kultural karena munculnya pro dan kontra tentang legalitasnya. Patut menjadi catatan, bahwa secara yuridis formal dalam hukum pidana positif di Indonesia hanya dikenal satu bentuk eutanasia, yaitu eutanasia yang dilakukan atas permintaan pasien/korban itu sendiri (voluntary euthanasia) sebagaimana secara eksplisit diatur dalam Pasal 344 KUHP. Pasal 344 KUHP secara tegas menyatakan: "Barang siapa merampas nyawa orang lain atas permintaan orang itu sendiri yang jelas dinyatakan dengan kesungguhan hati diancam dengan pidana penjara paling lama dua belas tahun".

Peraturan mengenai tindakan eutanasia di negara Indonesia hanya disebutkan secara tersirat dalam Pasal 344 KUHP dan hingga sekarang belum ada perumusan kembali mengenai pasal yang memuat tentang eutanasia secara jelas dan terperinci. Padahal kita mengetahui bersama bahwa eutanasia sekarang ini bukan lagi sebuah hal yang tabu bagi masyarakat umum di Indonesia. Hal ini dapat dilihat dari beberapa permohonan eutanasia di beberapa pengadilan negeri di Indonesia seperti yang terjadi di Aceh dan Kalimantan Timur pada beberapa tahun 
belakangan ini. Walaupun pada akhirnya permohonan tersebut ditolak oleh pengadilan negeri yang bersangkutan tetapi dapat dilihat bahwa fenomena eutanasia sudah mulai ada di Indonesia ${ }^{7}$.

Bertolak dari ketentuan Pasal 344 KUHP tersebut disimpulkan penulis bahwa pembunuhan atas permintaan korban sekalipun tetap diancam pidana bagi pelakunya. Dengan demikian, dalam konteks hukum positif di Indonesia eutanasia tetap dianggap sebagai perbuatan yang dilarang serta dalam konteks hukum positif di Indonesia tidak dimungkinkan dilakukan "pengakhiran hidup seseorang" sekalipun atas permintaan orang itu sendiri. Perbuatan tersebut tetap dikualifikasi sebagai tindak pidana, yaitu sebagai perbuatan yang diancam dengan pidana bagi siapa yang melanggar larangan tersebut. Mengacu pada ketentuan tersebut di atas, maka munculnya kasus permintaan tindakan medis untuk mengakhiri kehidupan yang muncul akhir-akhir ini (kasus Hasan Kesuma yang mengajukan suntik mati untuk istrinya, Ny. Agian dan terakhir kasus Rudi Hartono yang mengajukan hal yang sama untuk istrinya, Siti Zuleha) perlu dicermati secara hukum ${ }^{8}$. Kedua kasus ini secara konseptual dikualifikasi sebagai non voluntary euthanasia, tetapi secara yuridis formal (dalam KUHP) kasus ini tidak bisa dikualifikasi sebagai eutanasia sebagaimana diatur dalam Pasal 344 KUHP. Secara yuridis formal kualifikasi (yang paling mungkin) untuk kedua kasus ini adalah pembunuhan biasa sebagaimana dimaksud dalam Pasal 338 KUHP, atau pembunuhan berencana sebagaimana dimaksud dalam Pasal 340 KUHP. Dalam ketentuan Pasal 338 KUHP secara tegas dinyatakan, "Barang siapa sengaja merampas nyawa orang lain diancam, karena pembunuhan dengan pidana penjara paling lama lima belas tahun”. Sementara dalam ketentuan Pasal 340 KUHP dinyatakan: “ Barang siapa dengan sengaja dan dengan rencana lebih dulu merampas nyawa orang lain diancam, karena pembunuhan berencana, dengan pidana mati atau pidana penjara seumur hidup atau selama waktu tertentu paling lama dua puluh tahun".

Di luar dua ketentuan di atas menurut penulis juga terdapat ketentuan lain yang dapat digunakan untuk menjerat pelaku eutanasia, yaitu ketentuan Pasal 356 (3) KUHP yang juga mengancam terhadap "Penganiayaan yang dilakukan dengan memberikan bahan yang berbahaya bagi nyawa dan kesehatan untuk dimakan atau diminum". Selain itu patut juga diperhatikan adanya ketentuan dalam Bab XV KUHP khususnya Pasal 304 dan Pasal 306 (2). Dalam ketentuan Pasal 304 KUHP dinyatakan, "Barang siapa dengan sengaja menempatkan

7 Djoko Prakoso, Euthanasia: Hak Asasi Manusia dan Hukum Pidana, Jakarta: Ghalia Indonesia, 1984.

8 Hardiati Koeswadji, Hukum Kedokteran. Studi tentang Hubungan Hukum dalam Mana Dokter sebagai Salah Satu Pihak, Jakarta: PT. Aditya Bakti, 1998, hlm. 17. 
atau membiarkan seorang dalam keadaan sengsara, padahal menurut hukum yang berlaku baginya atau karena persetujuan, dia wajib memberikan kehidupan, perawatan atau pemeliharaan kepada orang itu, diancam dengan pidana penjara paling lama dua tahun delapan bulan atau denda paling banyak tiga ratus rupiah". Sementara dalam ketentuan Pasal 306 (2) KUHP dinyatakan, "Jika mengakibatkan kematian, perbuatan tersebut dikenakan pidana penjara maksimal sembilan tahun". Dua ketentuan terakhir tersebut di atas memberikan penegasan, bahwa dalam konteks hukum positif di Indonesia, meninggalkan orang yang perlu ditolong juga dikualifikasi sebagai tindak pidana. Dua pasal terakhir ini juga bermakna melarang terjadinya eutanasia pasif yang sering terjadi di Indonesia ${ }^{9}$.

Berdasarkan uraian yang penulis telah paparkan baik dalam konteks sistem hukum maupun dalam konteks peraturan perundang-undangan baik di Indonesia maupun di Negara yang melegalkan eutanasia seperti Belanda, Amerika, Swiss, Belgia, Kanada yang memiliki prinsip yang sama bahwa eutanasia adalah perbuatan yang melanggar hak hidup orang lain sebagai hak kodrati yang diberikan tuhan kepada setiap individu manusia. Namun demikian, di negara-negara yang melegalkan eutanasia sebagai suatu perbuatan yang dapat didekriminalisasi juga didasarkan pada alasan-alasan yang rasional untuk diterapkan, apabila ada permintaan yang sungguh-sungguh dari seseorang secara langsung meskipun pelaksanaan eutanasia tetap didasarkan pada penilaian dewan mahkamah agung sebelum diputuskan boleh atau tidaknya eutanasia dilakukan.

Fleksibilitas eutanasia di negara-negara yang melegalkan eutanasia menunjukkan bahwa hak mati adalah bagian hak yang perlu dilaksanakan dan dihormati. Oleh sebab itu, mati dalam konteks negara-negara tersebut juga merupakan hak dimana negara memiliki kewajiban untuk mewujudkannya. Untuk itu, dinamika eutanasia cukup berkembang di negara-negara yang melegalkan eutanasia bahkan negara tersebut adalah negara yang sangat menghormati hak asasi manusia. Untuk itu, penulis dapat menyimpulkan bahwa hak kematian merupakan bentuk hak asasi manusia.

Berbeda kemudian di Indonesia di mana ruang hukum bagi pelaksanaan eutanasia tidak diatur, sebab eutanasia dalam konteks hukum positif Indonesia dianggap sebagai tindak pidana yang dapat dimintakan pertanggungjawaban pidana. Dalam praktik empiris permohonan eutanasia di Indonesia telah dipraktikkan, namun demikian permohonan tersebut ditolak dengan alasan bahwa eutanasia merupakan perbuatan melawan hukum di dalam Hukum

\footnotetext{
$9 \quad$ Ibid.
} 
pidana dan melanggar hak asasi manusia, meskipun permohonan dilakukan secara sungguhsungguh. Dalam rangka mewujudkan dekriminalisasi eutanasia di Indonesia perlu mencontoh praktik eutanasia di negara-negara yang mengedepankan hak asasi manusia. Negara-negara yang melegalkan praktik ini misalnya Swiss, Belanda, Belgia, Kanada, Australia, Amerika Serikat, dan Perancis ${ }^{10}$. Dekriminalisasi eutanasia di Indonesia sangat dimungkinkan dilakukan jika paradigma hak mati merupakan bagian dari hak asasi manusia dengan catatan bahwa kematian yang diharapkan secara sungguh-sungguh dari pihak yang bersangkutan bukan berasal dari keluarganya. Oleh sebab itu, di Indonesia melalui Mahkamah Agung dapat menjadi lembaga yang bertugas melakukan penilaian atas permohonan eutanasia dengan prosedur yang ditetapkan di dalam peraturan hukum di masa yang akan datang. Untuk itu, seorang dokter di Indonesia hanya dapat melakukan eutanasia apabila mendapatkan persetujuan dan/atau penetapan oleh Mahkamah Agung sebagai lembaga yudikatif. Dekriminalisasi eutanasia dapat menjadi peniadaan pertanggungjawaban pidana di masa yang akan datang dalam konsep sistem hukum pidana di Indonesia.

\section{Kebijakan Hukum Pidana tentang Dekriminalisasi Eutanasia}

Kebijakan hukum pidana dekriminalisasi eutanasia dapat diwujudkan dalam sistem hukum pidana di Indonesia melalui pendekatan perbandingan, pendekatan kasus, pendekatan konseptual dan pendekatan perundang-undangan dalam rangka mewujudkan dekriminalisasi eutanasia secara komprehensif demi mewujudkan kepastian hukum. Oleh sebab itu, dekriminalisasi eutanasia dapat menjadi konsep baru dalam sistem hukum pidana di Indonesia. Penerapan dekriminalisasi eutanasia dalam konsep kebijakan hukum pidana tetap memperhatikan aspek moralitas hukum serta norma-norma lain yang tumbuh dan berkembang di Indonesia, sehingga konsep baru tentang dekriminalisasi eutanasia dapat diterima bagi masyarakat hukum di Indonesia dan tidak dipandang kebijakan hukum pidana tersebut sebagai konsep dan/atau teori yang bertentangan dengan Pancasila dan Undang-undang Dasar Negara Indonesia sebagai sumber dari segala sumber hukum dan juga merupakan titik anjak dari keseluruhan norma.

10 Luthfia Ayu Azanella, "Apa Itu Euthanasia dan Negara Mana Saja yang Melegalkan? ", Kompas.com. https://www.kompas.com/tren/read/2020/11/02/144500665/apa-itu-euthanasia-dan-negara-manasaja-yang-melegalkan-?page=all, diakses pada tanggal 17 Juli 2021. Lihat juga dalam "The countries where euthanasia is legal", The Week, https://www.theweek.co.uk/102978/countries-where-euthanasia-islegal, diakses pada tanggal 17 Juli 2021. 
Di Indonesia menurut penulis perlu dilakukan kebijakan hukum pidana dekriminalisasi eutanasia mengingat di negara-negara yang menganut sistem hukum Eropa Kontinental maupun Negara Anglo Saxon telah melegitimasi dekriminalisasi eutanasia sebagai perbuatan yang bukan melanggar hukum tentunya dengan alasan-alasan yang kuat. Untuk itu, dekriminalisasi eutanasia dalam kebijakan hukum pidana di Indonesia dimungkinkan dapat diwujudkan pelaksanaannya dalam sistem hukum pidana di masa yang akan datang. Sebab, acapkali eutanasia masih menjadi persoalan yang dianggap sebagai perbuatan pidana.

Beberapa bentuk kebijakan hukum pidana tentang dekriminalisasi eutanasia yang dapat diterapkan di Indonesia sebagai alasan dimungkinkannya eutanasia dilakukan secara legal dalam konteks hukum pidana sebagai berikut:

1. Dekriminalisasi eutanasia hanya dapat dilakukan terhadap pasien yang dalam keadaan menderita terus menerus, tak tertahankan dan tidak dapat disembuhkan.

2. Dekriminalisasi eutanasia dapat dilakukan berdasarkan hasil penelitian medis terpadu, dalam hal ini melibatkan seluruh dokter dari berbagai bidang keahlian.

3. Kebijakan hukum pidana dekriminalisasi eutanasia dapat dilakukan apabila permintaan untuk mati harus dilakukan secara sukarela, independen dan terus menerus.

4. Kebijakan hukum pidana dekriminalisasi eutanasia ditujukan terhadap pasien harus sakit parah dengan penderitaan psikis dan fisik.

5. Kebijakan hukum pidana dekriminalisasi eutanasia pasien yang berumur 12 tahun memerlukan persetujuan dari orang tua.

6. Kebijakan hukum pidana dekriminalisasi eutanasia hanya dapat dilakukan berdasarkan penetapan Mahkamah Agung berdasarkan permohonan pasien melalui keluarganya.

7. Kebijakan hukum pidana dekriminalisasi eutanasia harus dimaknai bahwa mati atas permohonan seseorang merupakan suatu hak asasi manusia dan bukan pelanggaran hak asasi manusia.

8. Definisi hukum hak mati juga perlu dirumuskan di dalam peraturan perundangundangan dan tidak hanya sebatas hak hidup.

Berdasarkan uraian di atas, penulis juga menyadari bahwa praktik dekriminalisasi eutanasia di Swiss yang menyediakan klinik kematian bagi orang-orang yang ingin mengakhiri hidupnya karena alasan non medis seperti yang dimohonkan oleh David Goodal tidak dapat dijadikan referensi kebijakan hukum pidana dekriminalisasi eutanasia di Indonesia, sebab 
sangat bertentangan dengan moralitas hukum yang tumbuh dan berkembang di Indonesia seperti norma agama dan norma hukum adat.

Dekriminalisasi eutanasia di Indonesia menurut penulis hanya dapat diwujudkan karena alasan kesehatan dan permohonan sungguh-sungguh dari pasien dan telah mendapatkan penetapan dari Mahkamah Agung berdasarkan hasil penilaian dokter terhadap pasien. Selain hal itu, penulis tidak sependapat jika klinik kematian diperlukan dalam mengakhiri hidup seseorang, karena hal tersebut akan menimbulkan preseden buruk oleh masyarakat Indonesia, meskipun hak untuk mengajukan permohonan kematian eutanasia di satu sisi wajib dihormati.

Berdasarkan hasil perbandingan penelitian yang telah dilakukan penulis diperoleh pandangan bahwa tidak semua praktik dekriminalisasi eutanasia yang diterapkan beberapa negara yang menganut sistem Anglo Saxon dan Eropa Kontinental sesuai dengan karakteristik masyarakat hukum Indonesia. Untuk itu, memerlukan pengkajian yang lebih utuh dan komprehensif jika dekriminalisasi eutanasia penting untuk diwujudkan. Dan menurut penulis jika melihat dari sistem hukum, maka Belanda dapat menjadi rujukan praktik penerapan dekriminalisasi eutanasia karena secara historis Indonesia memiliki sistem hukum yang sama dengan Belanda dan Belgia serta konsep hukum pidana di Indonesia saat ini juga berasal dari Belanda, sehingga dimungkinkan ruang hukum penerapan dekriminalisasi eutanasia dapat diwujudkan dalam konteks kebijakan hukum pidana di masa yang akan datang.

Hasil penelitian penulis juga menunjukkan pelaksanaan eutanasia memang wajib melalui penetapan Mahkamah Agung seperti Belanda, Belgia dan beberapa negara bagian di Amerika, namun ruang penetapan Mahkamah Agung tersebut diatur di dalam peraturan perundang-undangan, untuk itu secara prinsipiil dekriminalisasi eutanasia diatur di dalam undang-undang, meskipun melalui penetapan Mahkamah Agung.

\section{KESIMPULAN}

Eutanasia dapat dekriminalisasi di Indonesia, meskipun saat ini eutanasia merupakan tindak pidana yang dapat dimintakan pertanggungjawaban pidana. Namun demikian, ruang hukum dekriminalisasi eutanasia perlu diatur, mengingat dalam praktik empiris permohonan eutanasia kepada dokter sering diajukan oleh pasien dan keluarganya dengan alasan kesehatan. dekriminalisasi eutanasia harus dapat diberikan ruang hukum sebagaimana yang telah dipraktikkan di negara-negara yang menganut sistem hukum yang sama dengan Indonesia seperti Belanda dan Belgia dan bahkan di negara Anglo Saxon seperti Amerika dan 
Australia telah memberikan ruang hukum dekriminalisasi eutanasia, oleh sebab itu konsep dekriminalisasi eutanasia dapat saja diwujudkan melalui pendekatan perbandingan hukum. Dekriminalisasi eutanasia hanya dapat diwujudkan apabila ada permohonan sungguhsungguh dan terus menerus dari pasien dan secara medis tidak dapat disembuhkan berdasarkan kesimpulan dokter. Selain itu, kebijakan hukum pidana tentang dekriminalisasi eutanasia yaitu Dekriminalisasi eutanasia hanya dapat dilakukan terhadap pasien yang dalam keadaan menderita terus menerus, tak tertahankan dan tidak dapat disembuhkan, Dekriminalisasi eutanasia dapat dilakukan berdasarkan hasil penelitian medis terpadu, dalam hal ini melibatkan seluruh dokter dari berbagai bidang keahlian, Kebijakan hukum pidana dekriminalisasi eutanasia dapat dilakukan apabila permintaan untuk mati harus dilakukan secara sukarela, independen dan terus menerus, Kebijakan hukum pidana dekriminalisasi eutanasia ditujukan terhadap pasien harus sakit parah dengan penderitaan psikis dan fisik, Kebijakan hukum pidana dekriminalisasi eutanasia pasien yang berumur 12 tahun memerlukan persetujuan dari orang tua, kebijakan hukum pidana dekriminalisasi eutanasia hanya dapat dilakukan berdasarkan penetapan Mahkamah Agung berdasarkan permohonan pasien melalui keluarganya, kebijakan hukum pidana dekriminalisasi eutanasia harus dimaknai bahwa mati atas permohonan seseorang merupakan suatu hak asasi manusia dan bukan pelanggaran hak asasi manusia, dan definisi hukum hak mati juga perlu dirumuskan di dalam peraturan perundang-undangan dan tidak hanya sebatas hak hidup. Selain itu, dekriminalisasi eutanasia hanya dapat dilakukan di Indonesia dengan alasan kesehatan bukan alasan usia, alasan keluarga dan alasan psikis.

\section{Daftar Pustaka}

\section{Buku}

Astuti, Endang Kusumah, Hubungan Hukum Antara Dokter dan Pasien Dalam Upaya Pelayanan Medis, Bandung: Citra Aditya Bakti, 2003.

Hardiati Koeswadji, Hukum Kedokteran. Studi tentang Hubungan Hukum dalam Mana Dokter sebagai Salah Satu Pihak, Jakarta: PT. Aditya Bakti, 1998.

Prakoso, Djoko, Euthanasia: Hak Asasi Manusia dan Hukum Pidana, Jakarta: Ghalia Indonesia. 


\section{Jurnal dan Makalah}

Handrawan, “Pemulihan Hak Politik Melalui Mekanisme Konstitusional”, Halu Oleo Law Review, Volume 2 Issue 1, March 2018.

Hidayat, Sabrina, "Evidence Doctor Error in Alleged of Criminal Act on Medical Malpractice", International Journal of Scientific \& Technology Research Volume 4, Issue 02, February 2015.

\section{Peraturan Perundang-undangan}

Undang-Undang Dasar Negara Republik Indonesia Tahun 1945

KUHPidana Berdasarkan Undang-Undang Negara Republik Indonesia Nomor 1 Tahun 1946

Tanggal 26 Februari 1946 Tentang Peraturan Hukum Pidana Indonesia (Berita Republik Indonesia II Nomor 9).

Undang-Undang Negara Republik Indonesia Nomor 39 Tahun 1999 tentang Hak Asasi Manusia

(Lembaran Negara Republik Indonesia Tahun 1999 Nomor 165, Tambahan Lembaran Negara Republik Indonesia Nomor 3886).

Undang-Undang Negara Republik Indonesia Nomor 36 tahun 2009 Tentang Kesehatan

(Lembaran Negara Republik Indonesia Tahun 2009 Nomor 144, Tambahan Lembaran Negara Republik Indonesia Nomor 5063)

SK PB IDI Nomor.319/PB/4/1988 Tentang Pernyataan Dokter Indonesia tentang Mati

\section{Situs Web}

"Kasus Ny Agian, RS Telah Lakukan Euthanasia Pasif", Detikcom, 16 Oktober 2004, https://news.detik.com/berita/d-225608/kasus-ny-agian-rs-telah-lakukaneuthanasia-pasif, diakses pada tanggal 17 April 2021.

"The countries where euthanasia is legal", The Week, https://www.theweek.co.uk/102978/countries-where-euthanasia-is-legal, diakses pada tanggal 17 Juli 2021.

Luthfia Ayu Azanella, "Apa Itu Euthanasia dan Negara Mana Saja yang Melegalkan? ", Kompas.com. https://www.kompas.com/tren/read/2020/11/02/144500665/apaitu-euthanasia-dan-negara-mana-saja-yang-melegalkan-?page=all, diakses pada tanggal 17 Juli 2021.

Onwuteaka-Philipsen, Bridge D., "Euthanasia and other end-of-life decisions in the Netheroands in 1990, 1995 and 2001", The Lancet, Juni 2003, 
http://image.thelancet.com/extras/03art3297web.pdf, diakses pada tanggal 17 April 2021.

Tilamuhu, Irna, "Euthanasia Ditinjau Dari Aspek Hukum dan KUHP Indonesia", http://irnatilamuhu.blogspot.com/2012/03/euthanasia-ditinjau-dari-aspekhukum.html. diakses pada tanggal 3 Februari 2019. 